\title{
Immunoglobulins in aqueous humour and iris from patients with endogenous uveitis and patients with cataract
}

\author{
T. GHOSE, J. H. QLIGLEY, P. L. LANDRIGAN, AND A. ASIF \\ From the Departments of Pathology', Ophthalmology', and Medicine, Dalhousie University, Halifax, \\ Vova Scotia, Canada
}

The scarcity of aqueous humour and uveal tissues from living patients has hampered studies on the immunological aspects of human eye diseases. There are many autopsy studies investigating the nature and amount of proteins in human aqueous, but it is known that the composition of aqueous humour changes very rapidly after death so that the validity of the results of these autopsy studies on the composition of aqueous humour is in doubt (Hemmingsen and Øther, I967; Dicckhues, I967; Allansmith, Whitney, McClellan, and Newman, i973). Application of radial immunodiffusion (Mancini, Carbonara, and Heremans, 1965) has enabled us to estimate quantitatively $\operatorname{IgG}, \operatorname{Ig} \mathrm{M}$, and $\operatorname{IgA}$ in the aqueous humour obtained before surgery from patients suffering from:

(i) Active chronic endogenous uveitis,

(ii) Narrow-angle glaucoma with no active inflammation,

(iii) Senile cataracts.

Small pieces of iris were also available from these patients for immunohistochemical study.

\section{Material and methods}

Samples of aqueous humour collected just before surgery, taking care not to contaminate the aqueous with blood, were centrifuged in small glass test-tubes $(6 \mathrm{~mm}$. diameter with conical bottom) at I, ooo G. max. for io min. to get rid of cells and tissue debris (if any). The clear supernatant was subjected to radial immunodiffusion in plates (Hyland Laboratories, California). Using a number of reference standards supplied by the Hyland Laboratories and the World Health Organization (W.H.O. Standard $67 / 87$, the lowest protein concentrations which could be reliably measured by this method were: IgG, $5 \mathrm{mg}$./10o ml.; IgM, $4 \mathrm{mg}$./ $100 \mathrm{ml}$.; IgA, $4 \mathrm{mg}$./ $100 \mathrm{ml}$.

To assess the reproducibility of this method of immunoglobulin determination, ten repeated measurements of each of the three immunoglobulin classes were performed on a diluted pooled specimen of normal human serum. The coefficient of variation (standard deviations/mean concentration $\times$ Ioo) of the $\operatorname{IgG}, \operatorname{IgM}$, and $\operatorname{IgA}$ determinations respectively were $\pm 6, \pm 4$, and \pm 7 per cent. Whenever the volume of aqueous humour was insufficient, the aqueous was subjected to immunoelectrophoresis against an antibody to whole human serum for qualitative detection of immunoglobulin fractions.

Freshly excised pieces of iris (about $2 \mathrm{cu} . \mathrm{mm}$.) were snapfrozen in a slurry of liquid nitrogen and isopentane $\left(-160^{\circ} \mathrm{C}\right.$. $)$ and stored at $-70^{\circ} \mathrm{C}$. Air-dried unfixed 2 to $3 \mu$ cryostat sections of iris as well as parallel sections fixed in 5 per cent. glacial acetic acid in ethanol at $-20^{\circ} \mathrm{C}$. for $15 \mathrm{~min}$. (Hijmans, Schuit, and Klein, 1969) were washed three times in phosphate buffered saline (PBS, 
$\left.\mathrm{o} \cdot 0 \mathrm{IM} ; \mathrm{pH}_{7} \cdot 1\right)$ and stained by the direct immunofluorescence method using fluorescein-isothiocyanate conjugated monospecific rabbit antisera against human $\operatorname{IgG}, \operatorname{IgM}, \operatorname{IgA}, \mathrm{C}_{3}\left(\beta_{1 \mathrm{c}}-\beta_{1 \mathrm{~A}}\right)$, fibrinogen, and albumin. All antisera were obtained from Hyland Laboratories (California) and were conjugated with crystalline fluorescein isothiocyanate isomer I (Baltimore Biological Laboratory, Baltimore, Maryland) by a method adapted from that of Clark and Shepard (1963). Conjugates were freed of overlabelled globulin molecules by passing them through a column of DEAE cellulose (Riggs, Loh, and Eveland, 1960). Only those conjugates having dye protein ratios varying from $1 \cdot 3$ to $4 \cdot 5$ were used in this study. All antisera gave a single line on immunoelectrophoresis against normal human serum both before and after labelling. For immunofluorescence, an immersion type darkground condenser with a toric lens underneath (Tiyoda) was fitted to a Zeiss Ultraphot II microscope. UG. $\mathrm{I} / \mathrm{I} \cdot 5 \mathrm{~mm}$. (Schott and Gen) and Wratten $2 \mathrm{~B}$ were used as primary and secondary filters respectively. The light source was a high-pressure mercury arc lamp (Osram HBO 200). Specificity of immunofluorescence was established by:

(I) The absence of staining of cryostat sections of normal human iris (obtained at autopsy or from surgically enucleated eyes) by these conjugated anti-sera;

(2) Absence of staining of sections of iris from uveitis patients after absorption of the fluoresceinated antisera as appropriate with the relevant immunoglobulin fraction, fresh normal human serum, or human plasma fractions I (fibrinogen) and V (albumin);

(3) Absence of staining of iris from uveitis patients with fluoresceinated rabbit antigoat or rabbit antihorse globulin;

(4) Absence or inhibition of staining after "blocking" of specific staining by prior exposure of sections to non-labelled antibodies (Ghose, Nairn, and Fothergill, 1962).

The findings of direct immunofluorescence staining were further confirmed by the sandwich method, treating sections first with unconjugated reagents and then, as appropriate, with fluorescein ated goat antirabbit globulin or rabbit antigoat glabulins with proper controls (Ghose, Nairn, andō Cerini, I968; Ghose and Nigam, 1972; McGiven, Ghose, and Nairn, 1967). The "sandwich"? immunofluorescence method was used also for the detection of antinuclear, antithyroid, and antiuveal tract antibodies, using undiluted and diluted sera, i.e. I/4 and I/16 dilutions with PBS (Ghose, and Cerini, I969; McGiven and others, 1967; McGiven and Ghose, 1968). The specificity of the anticomplement serum was also assessed by the sandwich method using known complement fixing antinuclear antibodies and fresh $\mathrm{AB}$ group normal human serum as the source of complement on cryostat sections of rat liver (McGiven and Ghose, 1968). The specificity of anti-IgG, anti-IgM, and anti-C 3 sera was further confirmed by:

(i) Staining of renal biopsies from several post-streptococcal and lupus nephritis patients in whom glomerular deposits consisting predominantly of IgM or IgG and $\mathrm{C}_{3}$ were previously identified;

(ii) Nuclear staining, using the fluoresceinated anti-IgG or anti-IgM sera after exposure of cryostat sections of rat liver to antinuclear sera known to have their antinuclear activity only in either the IgG or the IgM fraction (McGiven and Ghose, I968).

All sections of iris showing fractions of human immunoglobulins by the above methods also stained when treated with Research Standard A for fluoresceinated antibody to human immunoglobulins kindly supplied by the World Health Organization (W.H.O. Ref. No. 68/45). To eliminate the possibility of the reaction of the antiglobulin reagents with dried-up serum or exudate trapped in tissue spaces, all sections were washed for $15 \mathrm{~min}$. in three changes of PBS before exposure to the reagents. In addition, parallel sections from the lesion showing immunoglobulin deposits were washed overnight at $4^{\circ} \mathrm{C}$. either with PBS or acid citrate buffer $(0 \cdot 02 \mathrm{M} ; \mathrm{pH} 3 \cdot 2)$ to elute out globulin (McGiven and Ironside, 1968). Sections washed in the acid buffer were rewashed in PBS for 30 min. to adjust the $\mathrm{pH}$ before staining for immunoglobulin. All sections washed with PBS retained immunoglobulin, whereas those washed with citrate buffer lost most of their immunoglobulin content. Whenever there was enough tissue, pieces of iris were fixed in to per cent. buffered formalin embedded 
in paraffin and sections were stained with haematoxylin and eosin, Masson's trichrome (for collagen), elastic Van Gieson (for clastic fibres, ) Congo red for amyloid, and periodic acid-Schiff (PAS) for polysaccharides. After immunofluorescence examination, all sections were fixed in 10 per cent. formalin and stained with eosin and haematoxylin (Ghose and others, 1968). However, most biopsies were too small for both paraffin and cryostat sections. In addition to usual ophthalmological investigations, all the patients included in this study were screened for:

(i) History of hypersensitivity and autoimmune diseases and administration of immunosuppressive or any other relevant drugs;

(ii) Skin tests with tuberculin, histoplasmin, and toxoplasmin;

(iii) Serum electrophoresis;

(iv) VDRL test for syphilis;

(v) Serum antistreptolysin o titre;

(vi) Erythrocyte sedimentation rate;

(vii) Total eosinophil count;

(viii) Routine blood biochemistry.

\section{Results}

Pieces of iris and aqueous humour from eighteen patients with senile cataract, eight patients with endogenous active chronic uveitis, and three patients with narrow-angle glaucoma without any active inflammation could be adequately studied.

\section{Detection of autoantibodies in the serum}

Antinuclear factor (ANF) was found in the serum of one patient with severe active uveitis and in low titre in one cataract patient. Both the antinuclear factors gave homogenous type of nuclear staining. No other autoantibodies were scen in these sera, nor did any serum react with normal human uveal tissue.

\section{Detection of immunoglobulin and $C_{3}$ in excised iris}

Clumps of immunoglobulin (mostly $\mathrm{IgG}$ ) and $\mathrm{C}_{3}$ were found in the unfixed section of iris from both the eyes of one patient suffering from an acute exacerbation of bilateral chronic uveitis. Plasma cells and large mononuclear cells containing mostly IgG were also seen in the excised iris from both the eyes (Figure, overleaf). Similar IgG-containing cells were also found in the smears of the centrifuged deposit of aqueous humour from this patient.

The patient had been intermittently under local corticosteroid therapy for the last I I years (the total duration of her illness) and on the basis of a weakly-positive tuberculin reaction was also treated with isoniazid and PAS for about 3 years. However, at the time of her first admission (July, I970), the only relevant finding apart from extensive bilateral posterior synechiae and iris bombé was that this patient's serum contained ANF. The volume of aqueous humour obtained from the left eye of this patient was too small for quantitative determinations, and on immunoelectrophoresis it showed the presence of IgG, IgM, and IgA. Radial immunodiffusion to the aqueous from the right eye showed higher than usual amounts of immunoglobulins (Table, overleaf). Another iris biopsy was obtained from the right eye of this patient about a year later. She was treated with local and sytemic corticosteroids during this period and did not have any signs or symptoms of active uveitis at the time of biopsy. Immunofluorescence revealed only a few immunoglobulin-containing cells (mainly IgG) in the iris. Though the aqueous from the right eye obtained just before the second biopsy contained $9^{8} \mathrm{mg}$. per cent. of $\operatorname{IgG}$, there was no detectable amount of IgM or IgA in this sample. 


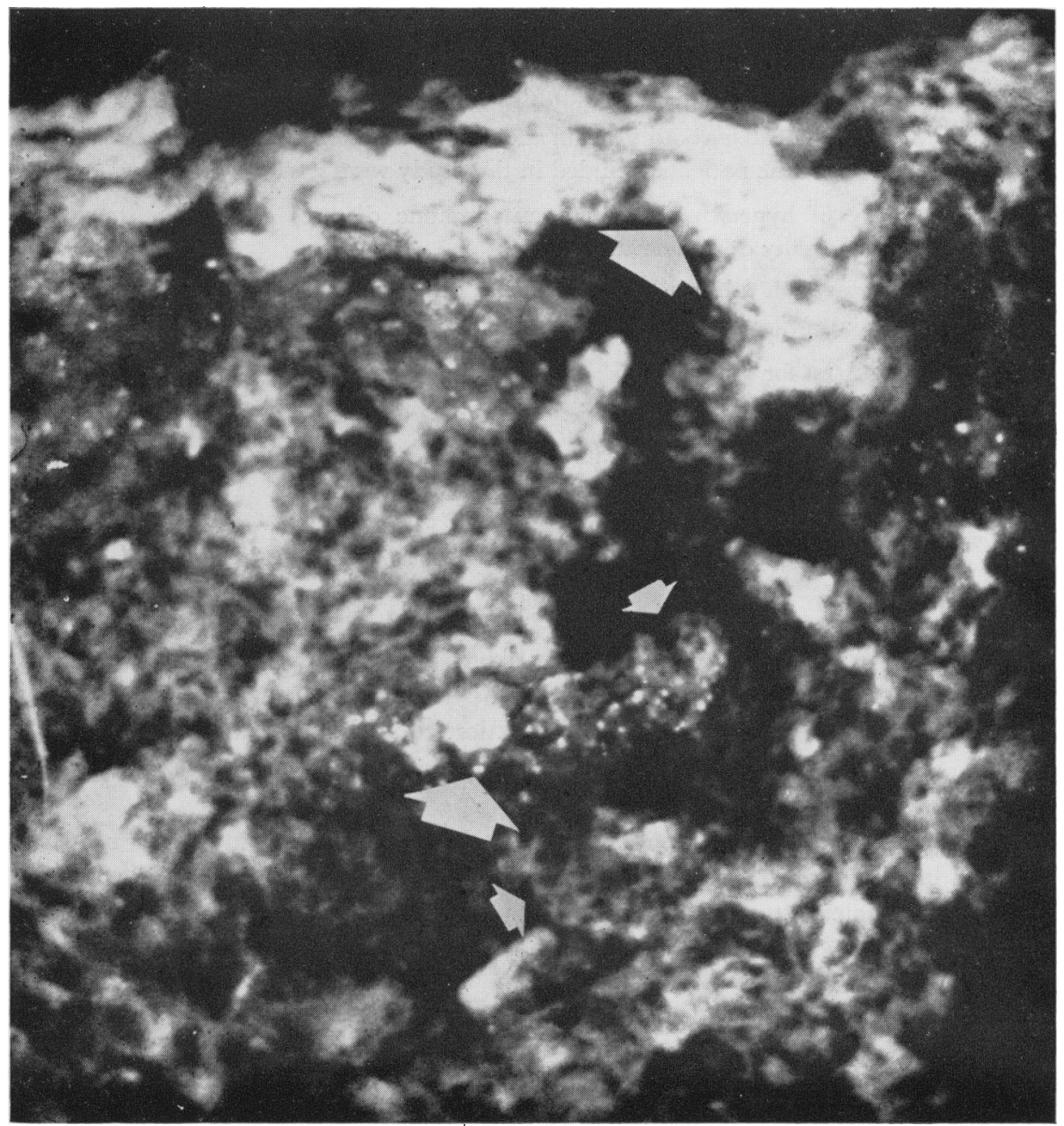

FIGURE Photomicrograph of an unfixed cryostat section of surgically excised iris (from a uveitis patient) treated with fluorescein-isothiocyanate conjugated rabbit globulin against human IgG. Note extracellular clumps of IgG (marked with large arrows) and the cytoplasmic fluorescence of the IgG-containing inflammatory cells (marked with small arrows). $\quad \times 850$

The iris biopsy from the seven other patients with active uveitis showed the presence of IgG, IgM, and IgA-containing cells, but no extracellular deposits of immunoglobulins or $\mathrm{G}_{3}$.

A small amount of extracellular IgG but not $\mathrm{C}_{3}$ was found in the fixed sections of iris from an 88-year-old woman who underwent an intracapsular cataract extraction and another 54-year-old male patient with narrow-angle glaucoma without active uveitis at the time of surgery. The aqueous humour from both these patients on immunoelectrophoresis showed IgG and IgA only. The results of other examinations of these two patients were unremarkable. Immunohistochemical examination of the other biopsies did not reveal intra- or extracellular immunoglobulin or $\mathrm{C}_{3}$. 
Table $\operatorname{Ig} G, \operatorname{Ig} M$, and $\operatorname{Ig} A$ content (expressed in $\mathrm{mg}$. per cent.) of human aqueous humour as determined by radial immunodiffusion

\begin{tabular}{|c|c|c|c|c|c|}
\hline $\begin{array}{l}\text { Age } \\
\text { (yrs) }\end{array}$ & Sex & Diagnosis & $I g G$ & $\operatorname{Ig} M$ & $\operatorname{Ig} A$ \\
\hline \multirow[t]{2}{*}{$50^{*}$} & F & Endogenous uveitis & $87 \cdot 0$ & $37 \cdot 5$ & $47 \cdot 0$ \\
\hline & & $\begin{array}{l}\text { Same patient after one } \\
\text { year }\end{array}$ & $98 \cdot 0$ & - & - \\
\hline $49 \dagger$ & F & Endogenous uveitis & $66 \cdot 5$ & $5^{\circ} 0$ & $10 \cdot 5$ \\
\hline $4^{8 \dagger}$ & $\mathbf{M}$ & Endogenous uveitis & $58 \cdot 0$ & $4 \cdot 5$ & $9 \cdot 4$ \\
\hline $63 \dagger$ & $\mathbf{M}$ & Endogenous uveitis & $58 \cdot 0$ & - & $6 \cdot 6$ \\
\hline $16 \dagger$ & $\mathrm{F}$ & Endogenous uveitis & $65 \cdot o$ & $7 \cdot 6$ & $6 \cdot 8$ \\
\hline 64 & F & Narrow-angle glaucoma & $8 \cdot 5$ & & $7 \cdot 0$ \\
\hline $5^{6}$ & $\mathbf{M}$ & Narrow-angle glaucoma & $5^{\cdot 0}$ & 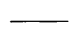 & 一- \\
\hline 63 & $\mathbf{M}$ & Senile cataract & $5^{\cdot 0}$ & - - & - \\
\hline 74 & $\mathbf{M}$ & Senile cataract & $5^{\circ} 0$ & $\ldots$ & - \\
\hline 88 & $\mathbf{M}$ & Senile cataract & $8 \cdot 0$ & - & $4^{\circ} 0$ \\
\hline 76 & $\mathbf{M}$ & Senile cataract & $7 \cdot 0$ & - & $4 \cdot 5$ \\
\hline 63 & $\mathrm{~F}$ & Senile cataract & $8 \cdot 5$ & - & - \\
\hline
\end{tabular}

* This patient showed deposits of IgG and $\mathrm{C}_{3}$ in iris

$\dagger$ These patients showed immunoglobulin containing cells in their iris

- Net detectable

Estimation of immunoglobulin in aqueous humour

Enough aqueous humour was available for quantitative determination of $\operatorname{IgG}, \operatorname{IgM}$, and IgA from five patients with active uveitis, two with narrow-angle glaucoma, and five with senile cataract. The amounts are presented in the Table. All the patients with active uveitis showed elevated levels of immunoglobulins in the aqueous humour compared with the other two groups of patients. IgM could be detected in the aqueous humour of four out of five patients with active uveitis. Immunoelectrophoresis of the aqueous of the three remaining patients with uveitis showed the presence of $\operatorname{IgG}, \operatorname{IgM}$, and IgA. IgG and $\operatorname{IgA}$ but not $\operatorname{IgM}$ could be detected by immunoelectrophoresis in the aqueous from the remaining patients with senile cataract and narrow-angle glaucoma. Thus, no IgM could be detected quantitatively or qualitatively (i.e. by immunoelectrophoresis) in the aqueous from any patient other than those suffering from endogenous uveitis. The serum level of $\operatorname{IgG}$, IgM, and $\operatorname{IgA}$ in these patients was within the range of normal values.

\section{Discussion}

Increased amounts of immunoglobulins in the aqueous from patients with active ocular inflammation has been reported (Allansmith and others, 1973) and this probably is the result of increased capillary permeability in the inflamed tissues. The observations that IgG (mol. wt I 50,000) and IgA (mol. wt I 70,000) could be detected in the aqueous from uninflamed eyes whereas IgM (mol. wt 950,00o) could be detected in the aqueous only in the presence of local inflammation might be related to the molecular size and related factors associated with the permeability of the different immunoglobulin classes through capillary walls (Allansmith and O'Connor, I970). The detection of immunoglobulin but not 
complement only in fixed tissue sections is perhaps of little relevance in the context of immunological mechanism of tissue damage. However, it is unlikely that the clumps을 of $\mathrm{C}_{3}$ containing immunoglobulin detected in the unfixed sections of iris from one of the patients with active uveitis was only dried up inflammatory exudate because $(i)$ albumin $\stackrel{\rho}{?}$ was not detectable in these preparations and (ii) the extracellular deposits of immunoglobulin could be washed off only with citrate buffer $\left(\mathrm{pH}_{3} \cdot 2\right)$ which dissociates tissue-bound $\frac{\overline{\bar{N}}}{\mathrm{~F}}$ antigen-antibody complexes (Freedman and Markowitz, I962; Edgington, Glassock, $\underset{\AA}{\mathbb{Q}}$ and Dixon, 1967) but not with PBS ( $\mathrm{pH} 7 \cdot \mathrm{I})$. The localization of $\mathrm{C}_{3}$ in those areas where extracellular deposits of immunoglobulin could be detected suggests that the $\vec{\circ}$

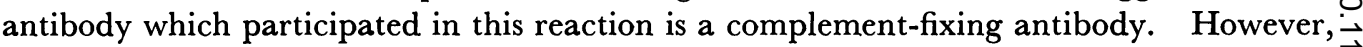
$\mathrm{C}_{3}$ could be bound by any immunoglobulin aggregate (Lachmann, Müller-Eberhard, $\vec{\omega}$ Kunkel, and Paronetto, 1962).

The precise mechanism of localization of extracellular immunoglobulin and $\mathrm{C}_{3}$ in the iris of this patient with uveitis has not been fully elucidated by our study. This localization $\vec{N}$ could have resulted from an immunological reaction of the host with an autologous or $\infty$ extrinsic antigen (Allansmith and O'Connor, 1970). Precipitating antibodies to human uveal antigen (Aronson and Maumenee, I97I) and complement-fixing antibodies to $\frac{\circ}{工}$ bovine uveal antigen (Luntz, I 968 ) have been found in the serum of a high proportion of $\vec{\sigma}$ patients with endogenous uveitis. However, no antibody reacting with uveal tissues was found by immunofluorescence in the serum of any of the patients with endogenous uveitis $\underset{3}{3}$ reported here. Therefore, if uveal tissue was damaged by an antigen-antibody reaction, $\mathbb{\Phi}$ the antigen is likely to be unrelated to uveal tissue. The possible mechanism of uve@l $\vec{\varphi}$ damage by antigen-antibody complexes and complement has recently been discuss (Allansmith and O'Connor, 1970; Wong, Anderson, and McMaster, 1971 ; Aronson ari Maumenee, I97I). Complexes of ANF and nucleoproteins have been implicated in tissue damage (McGiven and Ghose, 1968), but the clumps of immunoglobulin found in the iris of the uveitis patient when eluted out of cryostat sections with citrate buffered saline $\left(0.02 \mathrm{M}, \mathrm{pH}_{3} \cdot 2\right)$ showed neither antinuclear activity nor affinity for human uveal tissue. It is possible that the appearance of ANF in the serum of this patient might be due $\frac{0}{3}$ to isoniazid therapy (Alarcón-Segovia, Fishbein, and Betancourt, I969). Aqueous withdrawn from the right eye of this patient was consistently negative for bacterial and viral growth. Though the nature of the antigen in this complex is thus unknown, it is $\frac{0}{0}$. worth noting that experimental uveitis has been produced with a variety of antigen-음 antibody complexes where the allergen is unrelated to uveal tissue (Wong and others, 197I; Aronson and Maumenee, I97 I). The presence of immunoglobulin-producing cells in the iris of the endogenous uveitis patient is consistent with the observation that the uveal tract contains immuno-competent cells capable of producing specific antibody (Hall, I97ı; Silverstein, I964).

\section{Summary}

Aqueous humour and pieces of iris from eighteen patients with senile cataract, eight patients with endogenous uveitis, and three patients with narrow-angle glaucoma were examined for their immunoglobulin content. IgG was present in all the samples of aqueous, and IgA could be detected in most of the samples examined, whereas, IgM $\stackrel{\oplus}{\leftrightarrow}$ could be detected only in the aqueous of patients suffering from active endogenous uveitis. $T$ The amounts of IgG and IgA were usually higher in the aqueous from patients of endogen- $\stackrel{0}{\mathbb{D}}$ ous uveitis. Immunoglobulin-containing cells were present in the lesions of all the patients 
with endogenous uveitis. The biopsy of iris from one patient with endogenous uveitis showed, in addition to immunoglobulin-containing cells, complement $\left(\mathbf{C}_{3}\right)$-containing extracellular clumps of IgG.

Supported by a grant from the Department of National Health and Welfare, Canada Our thanks are due to Miss V. Cantelope for technical assistance.

\section{References}

alarcón-Segovia, D., fishbein, e., and betancourt, v. m. (1969) Clin. exp. Immunol., 5, 429 AllaNSMith, M. R., and o'ConNOR, G. R. (1970) Surv. Ophthal., 14, 367

\section{9, 36} , Whitney, G. R., MCclellan, B. H., and Newman, L. P. (1973) Arch. Ophthal. (Chicago),

ARonson, S. B., and maumenee, A. E. (I97 I) In "Immunological Diseases", ed. M. Samter, 2nd ed.,

vol. 2, p. I 3oo. Little, Brown, Boston

CLARK, H. F., and SHEPARD, c. c. (1963) Virology, 20, 642

DIEcKhues, B. (1967) "Allergie und Auge", Klin. Mbl. Augenheilk., Suppl. 48 (Bücherei des Augenarztes, Heft 48 )

EDgington, T. s., GLASSOCK, R. J., and Dixon, F. J. (1967) Science, 155, 1432

FREedman, P., and MARKowitz, A. S., (1962) Brit. med. F., I, I I 75

GHOSE, T., and CERINI, M. (1969) Clin. exp. Immunol., 5, $5^{1} 5$

-, NAIRN, R. C., and CERINI, M. (1968) Exp. Cell Res., 49, 513

- - - and Fothergill, J. E. (1962) Nature (Lond.), 196, i 108

- and Nigam, s. (1972) Cancer (Philad.), 29, 1398

HALL, J. M. (1971) Invest. Ophthal., ro, 775

hemmingsen, L., and øTher, A. (1967) Acta ophthal. (Kbh.), 45, 359

hijmans, w., sGhuit, H. R. E., and kLein, F. (1969) Clin. exp. Immunol., 4, 457

LAGhmanN, P. J., MÜLler-eberhard, H. J., KUNKel, H. G., and PARONetto, F. (1962) F. exp. Med., Ir5, 63

LUNTZ, м. H. (1968) Exp. Eye Res., 7, 561

MANCINI, G., CARBONARA, A. O., and heremans, J. F. (1965) Immunochemistry, 2, 235

MGGIVEN, A. R., and GHOSE, T. (1968) Clin. exp. Immunol., 3, 657

$\longrightarrow$, and NAIRN, R. C. (1967) Brit. med. F., 2, 19

-

RigGS, J. L., LOH, P. c., and eveland, w. c. (1960) Proc. Soc. exp. Biol. (N.Y.), ro5, 655

Silverstein, A. M. (1964) In "Immunopathology of Uveitis", ed. A. E. Maumenee and A. M.

Silverstein, p. 83. Williams and Wilkins, Baltimore

WONG, v. G., ANDERSON, R. R., and MCMASTER, P. R. B. (197I) Arch. Ophthal. (Chicago), 85, 93 